\title{
KEBIJAKAN PUBLIK UNTUK KESEJAHTERAAN RAKYAT
}

\author{
Agus Suryono \\ Universitas Brawijaya \\ agus_s@ub.ac.id
}

\begin{abstract}
Welfare of the people is one of the goals of the state. In certain mechanism is required to make it happen that is reflected in public policy is made. Issues related to the problems that arise in realizing kesejahkteraan through public policy challenge. The right strategy in providing public policy that supports the well-being of the people in overcoming social problems are very important for further investigation.
\end{abstract}

Keywords: Welfare of the people, public policy, social issues

Abstrak. Kesejahteraan rakyat merupakan salah satu tujuan bernegara. Dalam mewujudkannya diperlukan mekanisme tertentu yang tercermin dalam kebijakan publik yang dibuat. Berbagai hal terkait permasalahan yang timbul dalam mewujudkan kesejahteraan melalui kebijakan publik menjadi tantangan tersendiri. Strategi yang tepat dalam menyediakan kebijakan publik yang mendukung kesejahteraan rakyat dalam mengatasi masalah-masalah sosial sangat penting untuk dikaji lebih lanjut.

Kata kunci: Kesejahteraan rakyat, kebijakan publik, masalah sosial

Permasalahan kebijakan atau sering disebut sebagai implementation gap adalah suatu keadaan dalam proses kebijakan selalu terbuka akan kemungkinan perbedaan antara apa yang direncanakan oleh pembuat kebijakan dengan apa yang senyatanya dicapai sebagai hasil atau prestasi dari pelaksanaan kebijakan. Hal ini salah satunya dikarenakan dalam proses implementasi kebijakan seringkali dikumpul oleh banyak kepentingan dan harapan terutama pengaruh persepsi setting lingkungan dimana kebijakan itu dilaksanakan.

Dalam mewujudkan suatu produk kebijakan publik yang bernuansa kesejahteraan rakyat, masalahnya, bukan hanya terletak pada kemauan politik nasional (political will), tetapi juga pada pelaksanaan bertindak dari kemauan politik nasional tersebut (political action). Hal ini penting, mengingat bangsa Indonesia merupakan masyarakat yang majemuk/plural. Pengertian masyarakat majemuk secara horisontal ditandai adanya kesatuan-kesatuan sosial berdasarkan perbedaan-perbedaan suku bangsa, agama, adat istiadat, serta perbedaan kedaerahan. Sedangkan secara vertikal ditandai oleh adanya perbedaan-perbedaan kesenjangan (gap) yang cukup tajam antara masyarakat lapisan atas (elite) dan masyarakat lapisan bawah (grassroot). Fred. W.Riggs (1966) menyebutkan beberapa ciri masyarakat majemuk, antara lain: (1) Munculnya kelompok-kelompok elit yang merasa berkuasa (free riders); (2) Adanya sistem komunal, clect dan pemusatan-pemusatan kekuasaan (birokrasi); (3) Banyaknya norma-norma yang bertentangan dan membingungkan (anomie, permissif); (4) Adanya kelemahan dan kelonggaran dalam sistem kekuasaan dan pengawasan; (5) Adanya rintangan-rintangan yang komplek dan ketergantungan pada syndrome; (6) Heteroginity, formalism, overlapping, nepotism, poly normativism and lack of concencus, power distribution authority versus control. Kemajemukan struktur masyarakat sebagai jalinan unsur-unsur sosial dalam masyarakat terjadi karena adanya kelompok dalam masyarakat, kebudayaan, lembaga masyarakat, stratifikasi masyarakat, kekuasaan dan kewenangan dalam masyarakat.

Kebijakan dapat dimaknai lebih sebagai proses interaksi yang dilakukan negara dengan rakyat (Parsons, 1997). Kebijakan publik merupakan kebijakan yang dibuat dengan lingkup publik, yang merupakan lingkup bersama. Hal ini menggambarkan bahwa lingkup publik membutuhkan interaksi antara 
negara dengan warganya dalam pengambilan keputusan yang salah satunya terkait masalahmasalah sosial yang ada di masyarakat.

\section{Kesejahteraan Rakyat dan Kebijakan Publik}

Teori Negara Kesejahteraan (welfare state) pernah diperkenalkan oleh Spicker (Suharto, 2005) yang mendefinisikan negara kesejahteraan sebagai sebuah sistem kesejahteraan sosial yang memberi peran lebih besar kepada negara (pemerintah) untuk mengalokasikan sebagian dana publik demi menjamin terpenuhinya kebutuhan dasar warganya. Negara kesejahteraan ditujukan untuk menyediakan pelayanan-pelayanan sosial bagi seluruh penduduknya, sebaik dan sedapat mungkin. Negara kesejahteraan berupaya untuk mengintegrasikan sistem sumber dan menyelenggarakan jaringan pelayanan yang dapat memelihara dan meningkatkan kesejahteraan warga negara secara adil dan berkelanjutan. Artinya, bahwa negara kesejahteraan adalah adanya suatu negara, bahwa pemerintahan negara dianggap bertanggung jawab untuk menjamin standar kesejahteraan hidup minimum bagi setiap warga negaranya.

Konsep negara kesejahteraan sangat erat kaitannya dengan kebijakan sosial (social policy) yang di banyak negara mencakup strategi dan upaya-upaya pemerintah dalam meningkatkan kesejahteraan warganya, terutama melalui perlindungan sosial (social protection) yang mencakup jaminan sosial baik berbentuk bantuan sosial dan asuransi sosial, maupun jaring pengaman sosial (social safety nets).Sekurang-kurangnya ada lima bidang utama yang disebut Spicker untuk menjelaskan konsep kesejahteraan, yaitu: bidang kesehatan, bidang pendidikan, bidang perumahan, bidang jaminan sosial, dan bidang pekerjaan sosial.

Istilah kesejahteraan atau sejahtera dapat memiliki empat arti, yakni: (1) Dalam istilah umum, sejahtera menunjuk ke keadaan kondisi manusia yang baik, dimana orang-orangnya dalam keadaan makmur, dalam keadaan sehat, dan damai; (2) Dalam tinjauan ekonomi, sejahtera selalu dihubungkan dengan keuntungan atau manfaat kebendaan (ukuran materi) sebagai fungsi kesejahteraan sosial (secara formatif dan substantif bisa bermakna ekonomi kesejahteraan atau kesejahteraan ekonomi); (3) Dalam tinjauan kebijakan sosial, kesejahteraan sosial menunjuk ke jangkauan pelayanan untuk memenuhi kebutuhan masyarakat. Ini adalah istilah yang digunakan dalam ide negara kesejahteraan (welfare state); (4) Dalam tinjauan lain (seperti fenomena kebijakan di negara maju seperti Amerika), sejahtera menunjuk ke aspek keuangan yang dibayarkan oleh pemerintah kepada orang yang membutuhkan bantuan finansial, tetapi tidak dapat bekerja; atau yang keadaan pendapatan yang diterimanya untuk memenuhi kebutuhan dasar tidak cukup atau tidak layak secara manusiawi; atau jumlah yang dibayarkan biasanya jauh di bawah garis kemiskinan; atau bisa juga karena memiliki kondisi khusus, seperti adanya bukti sedang mencari pekerjaan (menganggur); atau kondisi lain, seperti ketidakmampuan atau kewajiban untuk menafkahi keluarga atau menjaga anak (yang mencegahnya untuk dapat/bisa bekerja), karena di beberapa kasus negara penerima dana diharuskan bekerja, yang dikenal dengan istilah workfare. Hal ini, tampaknya berbeda dengan yang terjadi di Indonesia, kasus Bantuan Langsung Tunai (BLT), Bantuan Langsung Sementara Tunai (BLST) atau bentuk-bentuk bantuan lain yang lebih bersifat kedermawanan (charity), yakni tidak ada kewajiban atau keharusan bagi penerima untuk bekerja.

Menurut kamus W.J.S Poerwadarminta (1990), sejahtera diartikan sebagai keadaan "aman, sentosa, dan makmur". Sehingga arti kesejahteraan meliputi kemanan, keselamatan dan kemakmuran. Adapun istilah rakyat (sosial) dalam arti sempit berkait dengan sektor pembangunan sosial atau pembangunan kesejahteraan rakyat yang bertujuan untuk meningkatkan kualitas kehidupan manusia, terutama yang dikatagorikan sebagai kelompok yang tidak beruntung dan kelompok rentan (kelompok yang berpotensi untuk menjadi orang miskin). Dalam hal ini, kebijakan pembangunan kesejahteraan rakyat pada umumnya menyangkut program-program atau pelayanan-pelayanan sosial untuk mengatasi masalah-masalah sosial seperti, kemiskinan, 
keterlantaran, ketidakberfungsian fisik dan psikis, tuna sosial, tuna susila, dan kenakalan remaja. Sebagai konsekuesinya, pengertian kebijakan kesejahteran rakyat seringkali diartikan sebagail kegiatan amal atau bantuan publik yang dilakukan pemerintah bagi keluarga miskin dan anak-anak mereka; yang oleh para pakar ilmu sosial dihubungkan dengan kondisi "Indeks Pembangunan Manusia/Human Development Index", yaitu: tinggi rendahnya tingkat hidup masyarakat yang dilihat dari tiga indikator utama: tingkat harapan hidup (expectation of life), tingkat pendidikan (literacy, education), dan tingkat pendapatan (income)./

Dengan demikian, konsep negara kesejahteraan tidak hanya mencakup deskripsi mengenai sebuah cara pengorganisasian kesejahteraan (welfare) atau pelayanan sosial (social services), melainkan juga sebagai sebuah konsep normatif atau sistem pendekatan ideal yang menekankan bahwa setiap orang harus memperoleh pelayanan sosial sebagai haknya. Oleh karena itu, konsep negara kesejahteraan ada juga yang menyebut sebagai anak kandung pergumulan ideologi dari teori sosialisme.

Anehnya, di dalam praktik kenegaraan konsep negara kesejahteraan ini justru banyak dilakukan dan berkembang di negara-negara demokratis dan kapitalis, bukan di negaranegara sosialis; yakni konsep Negara kesejahteraan sering dipandang sebagai sebuah strategi "penawar racun" konsep kapitalisme , yakni mengurangi dampak negatif dari sistem ekonomi pasar bebas, dengan menggunakan prinsip negara yang miskin (sakit) tidak mungkin membantu atau mensejahterakan rakyat atau warga negara yang miskin (sakit); Oleh karena itu, ada pula yang mengatakan bahwa sesungguhnya konsep welfare state itu tidak lain merupakan bentuk strategi dari kapitalisme yang baik hati (compassionate capitalism).

Perubahan kebijakan pembangunan publik selalu mengakibatkan perubahan sosial (kesejahteraan rakyat). Bahkan pembangunan adalah perubahan sosial itu sendiri. Perubahanperubahan sosial dalam pembangunan tidak saja bersifat positif, melainkan dapat pula bersifat negatif. Oleh karena itu, hal inilah yang selalu mendorong munculnya perhatian dan pemikiran terhadap pentingnya kebijakan publik dalam memandu kegiatan-kegiatan pembangunan.

Sebagai misal beberapa negara berkembang termasuk Indonesia, pengangguran, kemiskinan, kesenjangan sosial, kelangkaan pelayanan sosial merupakan masalah sosial utama sejak dulu sampai sekarang. Bahkan terjadi kecenderungan penurunan standar kehidupan karena berbagai perubahan sosial sejalan dengan proses transisi dari masyarakat agraris menuju masyarakat industri. Sementara masalah-masalah sosial konvensional seperti kemiskinan, kebodohan, dan keterbelakangan masih belum teratasi. Masalah-masalah sosial kontemporer, seperti perdagangan manusia, pengangguran, perilaku menyimpang, kenakalan remaja, dan eksploitasi terhadap anak kian muncul mewarnai fenomena kehidupan masyarakat modern. Oleh karena itu dalam konteks pembangunan nasional, kebijakan publik merupakan suatu perangkat, mekanisme, dan sistem yang dapat mengarahkan dan menerjemahkan tujuantujuan pembangunan.

Khusus, mengenai kebijakan publik yang berorientasi kepada pencapaian tujuan kesejahteraan rakyat, maka harus dimaknai dalam dua pengertian pokok, yaitu: memecahkan masalah kesejahteraan rakyat dan memenuhi kebutuhan sosialnya. Sehingga alur kebijakan publik dalam dimensi mencapai tujuan kesejahteraan rakyat adalah: (1) mengidentifikasi dan menentukan tujuan kesejahteraan rakyat; (2) Memecahkan masalah kesejahteraan rakyat; (3) Merumuskan kebijakan publik untuk kesejahteraan rakyat; dan, (4) Memenuhi kebutuhan sosial secara keseluruhan. Dalam kaitan ini, tujuan pemecahan masalah mengandung arti mengusahakan atau mengadakan perbaikan karena ada sesuatu keadaan yang tidak diharapkan (misalnya kemiskinan) atau kejadian yang bersifat destruktif atau patologis yang mengganggu dan merusak tatanan masyarakat. Tujuan pemenuhan kebutuhan mengandung arti menyediakan pelayananpelayanan sosial yang diperlukan, baik 
dikarenakan adanya masalah maupun tidak ada masalah, dalam arti bersifat pencegahan (mencegah terjadinya masalah, mencegah tidak terulang atau timbul lagi masalah, atau mencegah meluasnya masalah) atau pengembangan (meningkatkan kualitas suatu kondisi agar lebih baik dari keadaan sebelumnya).

Secara lebih rinci, tujuan-tujuan kebijakan publik yang berkaitan dengan kesejahteraan rakyat adalah: (1) Mengantisipasi, mengurangi, atau mengatasi masalah-masalah sosial yang terjadi di masyarakat.(2) Memenuhi kebutuhan-kebutuhan individu, keluarga, kelompok atau masyarakat yang tidak dapat mereka penuhi secara sendiri-sendiri melainkan harus melalui tindakan kolektif. (3) Meningkatkan hubungan intrasosial manusia dengan mengurangi kedisfungsian sosial individu atau kelompok yang disebabkan oleh faktor-faktor internal-personal maupun eksternal-struktural. (4) Meningkatkan situasi dan lingkungan sosial-ekonomi yang kondusif bagi upaya pelaksanaan peranan-peranan sosial dan pencapaian kebutuhan masyarakat sesuai dengan hak, harkat, dan martabat kemanusiaan. (5) Menggali, mengalokasikan dan mengembangkan sumber-sumber kemasyarakatan demi tercapainya kesejahteraan rakyat dan keadilan sosial.

Adapun untuk mencapai tujuan-tujuan kebijakan kesejahteraan rakyat, terdapat beberapa perangkat dan mekanisme kemasyarakatan yang perlu diubah, antara lain menyangkut: Pengembangan sumber-sumber, Pengalokasian status, dan Pendistribusian hak. Pengembangan sumber-sumber meliputi pembuatan keputusan-keputusan masyarakat dan penentuan pilihan-pilihan tindakan berkenaan dengan jenis, kualitas, dan kuantitas semua barang-barang dan pelayanan-pelayanan yang ada dalam masyarakat. Pengalokasian status menyangkut peningkatan dan perluasan akses serta keterbukaan kriteria dalam menentukan akses tersebut bagi seluruh anggota masyarakat. Kebijakan kesejahteraan rakyat harus memiliki efek pada penghilangan segala bentuk diskriminasi. Kebijakan sosial harus mendorong bahwa semua anggota masyarakat memiliki kesempatan yang sama untuk memperoleh pendidikan, pekerjaan yang layak, berserikat dan berkumpul dalam organisasi sosial, tanpa mempertimbangkan usia, jenis kelamin, status sosial ekonomi, ras, suku bangsa, dan agama. Pendistribusian hak menunjuk pada perluasan kesempatan individu dan kelompok dalam mengontrol sumbersumber material dan non-material. Ketiga aspek tersebut pada umumnya merupakan kerangka acuan pemerintah dalam menentukan tujuan kebijakan publik berkaitan dengan kesejahteraan rakyat. Jelasnya, bahwa kebijakan kesejahteraan rakyat harus memperhatikan distribusi barang dan pelayanan, kesempatan, dan kekuasaan yang lebih luas, adil dan merata bagi segenap warga masyarakat. Sehingga diharapkan pembangunan nasional dapat berjalan sesuai dengan tujuan nasional.

\section{Simpulan}

Oleh karena itu, rumusan kebijakan publik yang berkaitan dengan kesejahteraan rakyat dapat diartikan sebagai suatu sistem kebijakan pemerintah yang terorganisasi dari pelayananpelayanan dan lembaga-lembaga sosial, yang dirancang untuk membantu dan mendorong individu-individu dan kelompok-kelompok dalam masyarakat agar dapat mencapai tingkat hidup dan kesehatan yang maksimal (memuaskan). Dengan maksud agar tercipta hubungan-hubungan personal dan sosial yang memberikan kesempatan kepada individuindividu untuk mengembangkan kemampuankemampuan mereka seluas-luasnya dan meningkatkan kesejahteraan mereka sesuai dengan kebutuhan-kebutuhan yang diinginkannya. Untuk itu perlu di identifikasi tiga elemen pokok, yaitu: (1) sejauhmana masalah-masalah sosial ini diatur; (2) sejauhmana kebutuhan-kebutuhan dipenuhi, dan; (3) sejauhmana kesempatan dan peluang untuk meningkatkan taraf hidup rakyat dapat disediakan atau di fasilitasi.

Dengan demikian, esensi dari kebijakan publik untuk kesejahteraan rakyat, tidak lain tertumpu dan bertumpu pada sila kelima Pancasila sebagai landasan ideologi Negara Kesatuan Republik Indonesia, yaitu: Keadilan Sosial bagi seluruh rakyat Indonesia. Adapun 
keadilan sosial adalah memberikan hak-hak (sosial) kepada mereka-mereka yang memang punya hak (baik hak individu, maupun hak publik) sesuai dengan asas keseimbangan dan muderasi (proporsional). Ada dua bentuk keadilan, yaitu: (a) keadilan yang berbasis aturan hukum, nilai, dan norma-norma (yang seharusnya, Al-adalah), misal: konsep sama rata sama rasa dan konsep equity; dan (b) keadilan yang berbasis pertimbangan ekonomi (kemampuan manajemen, Al-Kitsu), yaitu mengupayakan distribusinya menjadi rata agar sama-sama merasakan dan dirasakan.

Oleh karena itu, dalam konteks ini diperlukan peran dan fungsi negara/state sebagai analog lembaga legal-formal yang dipercaya oleh rakyat untuk mengelola lahan kebun rakyat yang menghasilkan dan membagikan kembali hak-hak rakyatnya untuk kesejahteraan rakyat. Adapun tugas pemerintah analog dengan Satuan Pengamanan (Satpam) yang berkewajiban melindungi dan menjaga kebun rakyat dari segala ancaman, tantangan, hambantan, dan gangguan baik yang datangnya dari dalam negeri maupun dari luar negeri. Jika hal ini dapat dilakukan, maka kebijakan publik untuk kesejahteraan rakyat merefleksikan bahwa Negara atau pemerintahan yang ada telah melaksanakan asas pemerintahan yang demokratis, yaitu: dari rakyat, oleh rakyat, dan untuk (kesejahteraan) rakyat.

\section{DAFTAR PUSTAKA}

Suharto, Edi. 2005. Analisis Kebijakan Publik. Alfabeta. Bandung.

Parsons, USA: Wayne.1997. Public Policy: An Introduction to the Theory and Practice of Policy Analysis. Edward Elgar Publishing Limited UK. Edward Elgar Publishing Inc.

Riggs, Fred.W. 1964. Administration in Developing Countries: The Theory of Prismatic Society. Boston: Hougton Miffin Company.

Purwadarminta, W.J.S. 1990. Kamus Besar Bahasa Indonesia, Jakarta: Departemen Pendidikan dan Kebudayaan. 